KULTURA

i

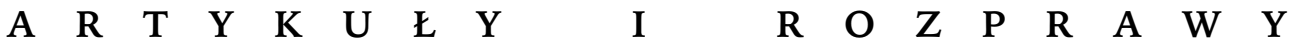

MACIEJ GDULA

Uniwersytet Warszawski

\section{SOCJOLOGIA KOŃCA SOCJOLOGII O KONCEPCJI TEORETYCZNEJ BRUNO LATOURA}

Zazwyczaj koncepcje teoretyczne przedstawia się lokując je na mapie „odwiecznych" dylematów, przed jakimi stoi teoria społeczna (np. indywidualizm-holizm albo naturalizm-antynaturalizm) i odtwarzając listę autorów, których idee miały szczególny wpływ na rozważaną teorię. Jeśli ktoś chce zastosować ten ugruntowany sposób postępowania do analizy koncepcji Bruno Latoura, najbardziej wpływowego przedstawiciela Actor-Network Theory (ANT), to powinien przypomnieć sobie zdanie otwierające jego Irreductions: „Nic nie jest samo w sobie ani redukowalne, ani nieredukowalne do niczego innego". Z pewnością możliwa jest redukcja koncepcji ANT do serii etykiet i nazwisk wielkich poprzedników, ale wtedy oddamy sprawiedliwość tylko drugiej połowie twierdzenia. Taki sposób postępowania mógłby zostać potraktowany jako dowód całkowitego zlekceważenia tez autora Nous n'avons jamais été modernes.

W stosunku do teorii rozwijanej przez Latoura konieczne jest zastosowanie innej strategii rekonstrukcji. Zamiast tworzenia czegoś w rodzaju krytycznego komentarza, metajęzyka pozwalającego zdać sprawę ze wszystkich tekstów Latoura ${ }^{1}$, będę starał się podążyć za opowieściami, jakie można $\mathrm{w}$ tych testach znaleźć, i zaprezentować specyfikę ANT przez pokazanie charakterystycznych dla niej paradoksów. Obserwacja paradoksów nie jest przy tym po prostu wykazywaniem nieścisłości czy słabości, ale ukazaniem warunków możliwości konstruowania teorii $\mathrm{w}$ określony sposób, a przy tym ukazywaniem logiki funkcjonowania procesów społecznych.

\section{Adres do korespondencji: mgdula@poczta.onet.pl}

1 Zob. B. Latour, The Enlightenment without the Critique: A Word on Michel Serres' Philosophy, w: J. Griffith (red.), Contemporary French Philosophy, Cambridge University Press, Cambridge, s. 83-98. Pamiętając o ograniczeniach związanych z rekonstrukcją pojęć Latoura, z jego podstawowymi kategoriami można zapoznać się w książce Ewy Binczyk Obraz, który nas zniewala. Wspótczesne ujęcia języka wobec esencjalizmu i problemu referencji, Universitas, Kraków 2007. 


\section{SOCJOLOGIA PO SOCJOLOGII}

Choć Bruno Latour czasami w ogóle zaprzecza, że tworzy teorię, to jednak $z$ jego prac wyłania się swoista koncepcja teoretyczna. Koncepcja ta nosi nawet cechy tzw. wielkiej teorii, to jest teorii nie ograniczającej się do analizy fragmentów rzeczywistości, obejmującej lub uchylającej ustalenia innych teorii i podejmującej próbę wyjaśnienia samej siebie na gruncie własnych pojęć. Rekonstrukcja zamysłu Latoura musi jednak uwzględniać fakt, że ideałem teorii nie jest dla niego „zespół praw (twierdzeń) uporządkowany tak, aby stanowiły one pewną wewnętrznie spójną konstrukcję logiczną"2. Odejście od tego wzorca nie jest motywowane niemożnością sprostania zbyt wysoko podniesionej poprzeczce, ale wynika z przeświadczenia o ograniczonych możliwościach poznawczych tak pojętego ideału.

Praca nad zespołem twierdzeń jest pracą redukcji, która polega na stworzeniu infrastruktury poznawczej pozwalającej sprowadzić zróżnicowaną rzeczywistość empiryczną do formul teoretycznych. Można powiedzieć, że jest to sprowadzanie tego, co inne, do tego samego. Latour stara się przyjąć odmienną perspektywę. Celem teorii nie jest sprowadzenie tego, co inne, do tego samego, ale oddanie sprawiedliwości temu, co inne, przez uznanie jego odmienności. To można zrobić tylko dystansując się zarówno od teorii socjologicznej, jak i od empiryzmu.

Latour sporo miejsca poświęca na wykazanie, czym ANT różni się od uznanych perspektyw socjologicznych ${ }^{3}$. Wyraźnie daje do zrozumienia, że jego stanowisko zasadniczo różni się od socjologii wiedzy, zarówno w jej klasycznym, jak i nieklasycznym wydaniu. Latour odrzuca przekonanie o możliwości bezstronnego naukowego poznania, charakterystyczne dla klasycznej socjologii wiedzy, skłonnej społecznych przyczyn wiedzy upatrywać wyłącznie w fałszywych teoriach i wadliwych ustaleniach badań naukowych. Jednocześnie Latour, akceptując punkt widzenia nieklasycznych socjologów wiedzy ${ }^{4}$, którzy utrzymują, że wszelka wiedza, w tym także naukowa, pozostaje skonstruowana, nie uznaje, że jest to konstrukcja zależna od kontekstu społecznego. Nieklasyczna socjologia wiedzy wszelką aktywność ma traktować jako efekt gier o władzę sprawowaną za pomocą rozmaitych środków, będących też nagrodami w walce, takich jak prestiż, pieniądze czy władza. Latour argumentuje, że nieklasyczna socjologia wiedzy lekceważy treść procesów społecznych i uważa teksty, rzeczy, technologię za różnokolorowe żetony, które dla przebiegu gry mają wyłącznie

\footnotetext{
2 S. Nowak, Metodologia badań socjologicznych, PWN, Warszawa 1970, s. 370.

3 Zob. np. B. Latour, One More Turn After Social Turn, w: E. McMullin (red.), The Social Dimensions of Science, University of Notre Dame Press, Notre Dame 1992, s. 273-294; B. Latour, Nous n'avons jamais été modernes, La Decouverte, Paris 1997; B. Latour, The Impact of Science Studies on Political Philosophy, „Science, Technology and Human Values” 1991, t. 16, nr 1, s. 3-19.

4 Latour, mówiąc o nieklasycznej socjologii wiedzy, ma na myśli przede wszystkim specyficznie przez niego interpretowane teorie Pierre'a Bourdieu i mocny program socjologii wiedzy.
} 
konwencjonalne znaczenie. Zmierza do wykazania, że rzeczywistość nie powstaje jako odzwierciedlenie kontekstu społecznego, ale jest konstruowana w konkretnych praktykach, w których ustanowione i ustabilizowane zostają relacje między aktorami, i to zarówno ludźmi, jak i nie-ludźmi - maszynami i rzeczami. Te relacje o różnej rozciągłości i stabilności tworzą sieci i to sieci są właściwą dziedziną teorii Latoura. Podobnie jak w filozofii, gdy po Heglu kolejni myśliciele (żeby wymienić tylko kilku: Marks, Nietzsche, Derrida) pokazywali, jak czysta filozofia jest niemożliwa i jak można uprawiać ją za pomocą innych środków, tak i Latour wskazuje, że czysta socjologia jest niemożliwa i pokazuje, jak mają wyglądać inne środki do jej uprawiania.

Analiza sieci musi realizować się $\mathrm{w}$ badaniach, ale Latour wyraźnie przestrzega przed empiryzmem. Co ciekawe, jego argumenty przypominają nieco krytykę, jaką skierował przeciw teorii. Empiryzm pozbawiony refleksji teoretycznej jest skazany na mimowolny redukcjonizm. Ten redukcjonizm jest może nawet bardziej niebezpieczny, bo zakrywa go złudzenie bezpośredniego kontaktu z rzeczywistością. Już w pierwszej książce, którą Latour napisał wraz ze Steve'em Woolgarem, pojawia się krytyka badań zadowalających się powierzchownym kontaktem z rzeczywistością empiryczną. Wskazując na trudności w socjologicznym badaniu nauk ścisłych, autorzy Laboratory Life zwracają uwagę, że kontakt socjologa $z$ naukowcami $z$ obszaru tych nauk zazwyczaj polega na wysłuchiwaniu ich opowieści o stosunkach władzy, nadużyciach i relacjach międzyludzkich w miejscu pracy ${ }^{5}$. Naukowcy ci wiedzą, czym zajmuje się socjolog, i dokonują za niego wstępnej redukcji pola badawczego, oszczędzając mu słuchania o badaniach nad enzymami czy sposobami hodowli bakterii. Inną ważną kwestią jest to, że narzędzia (np. statystyka), jakimi operują badacze społeczni, stanowią gotową infrastrukturę $z$ wbudowanymi założeniami co do tego, co warto badać i gdzie kończą się granice świata społecznego. Każda analiza sieci jest wyzwaniem dla badacza, ponieważ musi on zdystansować się wobec narzędzi, jakie oferują mu wyspecjalizowane i spontaniczne formy wiedzy teoretycznej.

Budowa aparatu poznawczego u Latoura odbywa się zawsze w konfrontacji $z$ konkretnym obszarem badawczym. Choć pewne pojęcia występują u Latoura $\mathrm{w}$ wielu tekstach, to $\mathrm{z}$ pewnością nie tworzą one trwałego, dobrze zdefiniowanego aparatu krytycznego. Pojęcia traktuje się jak narzędzia, których poręczność określają konkretne warunki analizy. Latour nie poświęca zbyt wiele uwagi definiowaniu relacji między nimi: „Muszę was ostrzec, mój poziom refleksyjności nad samym sobą jest praktycznie żaden. Wytwarzam książki, nie filozofię. Każda książka, jaka mnie pochłania, jest pracą pisarską, w której specyficznej strukturze towarzyszą swoiste pojęcia. Nie mogę przekształcić wszystkich moich książek w jednolity, stabilny w czasie obszar myślowy znajdujący spójny

5 B. Latour, S. Woolgar, Laboratory Life: The Construction of Scientific Facts, Princeton University Press, Princeton-New Jersey 1986, s. 19-21. 
wyraz w jednej książce" ${ }^{6}$. Trudno odmówić Latourowi konsekwencji w stosowaniu zasad ANT do niej samej.

\section{FRANCJA, HIGIENIŚCI, NAUKOWCY, PASTEUR, MIKROBY...}

Dobrą metodą na przedstawienie koncepcji Latoura jest podążenie za jedną $z$ jego analiz. W ten sposób można odsłonić specyfikę ANT i dać choć namiastkę niewątpliwej przyjemności, jaką czerpie się z lektury jego książek. Chyba najlepiej nadaje się do tego jedna $z$ najbardziej błyskotliwych jego prac Pasteurization of France $^{7}$, poświęcona przemianom, jakim podlegała dziewiętnastowieczna rzeczywistość $\mathrm{w}$ związku z wzięciem pod uwagę istnienia bakterii. W Pasteurization of France Latour dotyka najbardziej istotnych wątków teorii społecznej, takich jak porządek społeczny, władza, nowoczesność czy krytyka ${ }^{8}$.

Punktem wyjścia opowieści Latoura jest postać Ludwika Pasteura. Pasteur jest uznawany za geniusza, który odmienił nie tylko Francję, ale cały współczesny świat. Latour przestrzega jednak przed uwiedzeniem przez obraz geniusza zmieniającego świat wyłącznie dzięki sile swego umysłu. Odczarowanie Pasteura nie powinno też prowadzić do redukowania jego odkryć do kontekstu społecznego. Na odkrycia tego badacza trzeba spojrzeć jako na efekt połączenia wielu różnorodnych aktorów i elementów. Tu Latour nawiązuje do Tołstoja i jego opisu bitwy pod Tarutino. Choć chwała zwycięzcy spłynęła na Kutuzowa, któremu przypisywano genialny zmysł strategiczny, to bitwa toczyła się bez jego większego udziału. Oddziały przemieszczały się przypadkowo, część dowódców ociągała się, część atakowała zbyt szybko i z pewnością nie było jednego centrum dowodzenia zarządzanego przez genialnego stratega. Na Francję czasów Pasteura trzeba spojrzeć jak na pole bitwy, dokonać rozpoznania oddziałów, przeglądu sprzętu i przyjrzeć się ruchom wojsk. Niczego z góry nie rozstrzygać i nie rzutować wyniku działań na ich przebieg.

Latour dokonuje rekonstrukcji kilku wymiarów składających się na sytuację, w jakiej działał Pasteur. Ważnym wątkiem ówczesnej debaty we Francji była nagląca potrzeba reform, które nie byłyby wąsko polityczne, ale objęłyby

${ }^{6}$ Interview with Bruno Latour, w: D. Ihde, E. Selinger (red.), Chasing Technoscience: Matrix for Materiality, Indiana University Press, Bloomington 2003, s. 19.

7 B. Latour, Pasteurization of France, tłum. A. Sheridan, J. Law, Harvard University Press, Cambridge, Mass.-London 1993. Posługuję się tu angielską wersją książki, której przekład został przejrzany przez Latoura. Latour pisze zarówno po francusku, jak i po angielsku, sygnalizując $\mathrm{w}$ ten sposób dystans do częstej w humanistyce apoteozy nieprzekładalności, co nie powinno zbytnio dziwić, skoro jednym z głównych pojęć ANT, zdających sprawę z funkcjonowania sieci, jest translacja.

${ }^{8}$ Ta historia przedstawiona jest także w książce Radosława Sojaka Paradoks antropologiczny. Socjologia wiedzy jako perspektywa ogólnej teorii społeczeństwa, Wydawnictwo Uniwersytetu Wrocławskiego, Wrocław 2004, s. 234-238. Zdecydowałem się na rekonstrukcję opowieści o Pasteurze także dlatego, że przedstawiona przez Sojaka opowieść jest bardzo „pasteurocentryczna”, co prowadzi moim zdaniem - do zbytniej redukcji uwypuklonej przez Latoura społecznej sytuacji, w której działają Pasteur i jego współpracownicy. 
całe życie społeczne i wydźwignęły z nędznego poziomu życia wszystkich ludzi znajdujących się w opłakanym stanie ${ }^{9}$. W analizowanym przez Latoura „Revue Scientifique”, piśmie od połowy XIX wieku tworzonym przez uczonych dla szerszej, wyedukowanej publiczności, pojawiają się artykuły dotyczące zarówno medycyny, jak i gimnastyki, kolonizacji czy handlu międzynarodowego. Szczególne miejsce zaś przypadało problemowi depopulacji Francji, z czym wiązał się postulat stworzenia silnych, zdrowych ludzi. Impulsem dla rozwoju takich zainteresowań było pojawienie się $\mathrm{w}$ połowie XIX wieku ograniczeń $\mathrm{w}$ procesach tworzenia bogactwa, co wiązało się ze słabą jakością materiału ludzkiego - ludzie byli chorowici, niewykształceni, niesumienni i niezwiązani z miejscem. Przeciwdziałać temu miały środki uchodzące dziś za normę: powszechna opieka zdrowotna, powszechna edukacja, czyste, przewietrzone miasta, parki itp. ${ }^{10}$

Jednym $z$ aspektów sytuacji definiowanej jako kryzys było pojawianie się chorób, które dziesiątkowały populację zarówno ludzi, jak i zwierząt hodowlanych. Wzrost populacji wiązał się z problemem ich niestabilności. Choroby były uznawane za poważne zagrożenie i nie umieszczano ich już w tradycyjnym kontekście kary za grzechy, ale ujmowano jako problem ekonomiczny i kwestię jakości życia. Powstał wielki ruch higieniczny mający przeciwdziałać chorobom. Skupiał on tysiące ochotników, mobilizował energię i zasoby, ustanawiał cele i definiował zadania istotne dla lepszej organizacji życia społecznego ${ }^{11}$. Ruch ten rozpoczął walkę z chorobami, odwołując się do teorii ich samorodności, czyli powstawania $z$ brudu, wilgoci, zaduchu i zagęszczenia ludności.

Problemem ruchu higienicznego były niewystarczające efekty jego działań. Nie można było mieć zaufania do praktyk, które wydawały się jak najlepiej zaplanowane i odpowiednio przeprowadzone: na przykład piwo wysyłane było do klienta świeże, a docierało zepsute, dziecko odbierane przez lekarza po urodzeniu było zdrowe, a wkrótce umierało itd. Te komplikacje przypisywano różnym czynnikom: opieszałości władz, które nie postępowały wedle zaleceń, oporowi mas przed nowoczesnością i spontanicznemu wyradzaniu się chorób $^{12}$. To ostatnie pojęcie odgrywało kluczową rolę. Ponieważ choroby pojawiały się to tu, to tam, czasem zimą, czasem latem, niekiedy reagowały na leki, kiedy indziej pozostawały na nie obojętne, to przyjmowano, że za chorobę może być odpowiedzialne dosłownie wszystko i teza o „spontanicznej zachorowalności" wydawała się jedynym racjonalnym wyjaśnieniem. Choć czasami ruch higieniczny osiągał sukcesy i zastosowane środki pomagały, to nigdy nie można było wykluczyć i przewidzieć nagłego wybuchu epidemii. Ta nieprze-

\footnotetext{
9 B. Latour, Pasteurization of France, cyt. wyd., s. 17.

10 Tamże, s. 18.

11 Tamże, s. 25.

12 Tamże, s. 31-32.
} 
widywalność rodziła sceptycyzm co do sensowności podejmowanych działań higienicznych i zagrażała samemu ruchowi ${ }^{13}$.

Propozycja Pasteura, aby uznać, że choroby są powodowane przez jeden czynnik - bakterie - była diametralnie różna od teorii higienistów, która opierała się na wieloczynnikowej analizie przyczyn. Latour śledzi, jak stało się możliwe nakłonienie higienistów do zaakceptowania nowej definicji przyczyn chorób, i wskazuje, że Pasteur i jego ludzie nie ustawili bitwy, nie rozlokowali wojsk, ale wskazali wroga i kierowali ogniem.

Pasteur postanowił pokonać mikroby na terenie laboratorium. Nie były one jednak jedynym jego wrogiem. Dołączyli do nich także jego konkurenci w polu naukowym. Ponieważ w 1871 r. przyjmowano, że choroba jest czymś, co da się zrozumieć tylko na jej prawach, w konkretnym środowisku, Pasteurowi zarzucano niedostateczną naukowość. Krytykowano go za to, że dokonując eksperymentów w wypreparowanej przestrzeni laboratorium lekceważy specyficzny układ warunków środowiskowych odpowiedzialnych za powstawanie chorób. Odtwarzając postępowanie Pasteura, Latour wskazuje, że stawką w potyczkach naukowych jest nadanie głoszonym tezom statusu tez bezdyskusyjnych. Można to robić powołując się na autorytet metody naukowej, ale można też pójść inną drogą. Taką inną drogą było dla Pasteura laboratorium i umiejętność przekształcenia zasad, za pomocą których organizowano szersze praktyki społeczne. Dzięki temu mógł jednocześnie wygrać z mikrobami, przekonać do swoich tez higienistów i zdobyć przewagę nad konkurentami naukowymi.

Pierwszym krokiem w pracy laboratoryjnej Pasteura i jego współpracowników było przeniesienie laboratorium tam, gdzie występowała choroba i wyizolowanie odpowiedzialnych za nią bakterii. W tym celu udali się na farmę, gdzie wyizolowali bakterie wąglika. Drugim krokiem było przeniesienie się do bezpiecznego miejsca, gdzie można panować nad warunkami i osłabić zjawisko, z którym się walczy. W ten sposób konfrontacja z bakteriami następowała na terenie kontrolowanym przez naukowców, co oznaczało, że głoszone przez nich tezy albo nie mogły zostać podważone, albo mogły zostać podważone tylko na warunkach, jakie oni sami określali. Laboratorium stało się obszarem, w którym niewidoczny dotąd mikrob mógł się uwidocznić ze względu na brak konkurencji i dobre pożywienie. Pasteur stworzył hybrydę: eksperymentalną chorobę, która działała jak zwykła choroba, ale w kontrolowanych warunkach. W tych warunkach można było dokonać ustalenia, na co odporne są mikroby (np. czy umierają $\mathrm{w}$ moczu czy zabija je temperatura $100^{\circ} \mathrm{C}$ ) i co sprawia, że stają się słabsze, tak że łatwiej je pokonać za pomocą szczepionki. W tych kontrolowanych warunkach Pasteur mógł też pokazać hodowle bakterii tym, którzy wątpili w ich istnienie. W dodatku testy, jakim poddawał mikroby, umożliwiły znalezienie wspólnego języka $z$ higienistami. W laboratorium można było pokazać na przykład, że kurczaki nie zakażają się wąglikiem, chyba że przebywają

13 Tamże, s. 33. 
w niskich temperaturach. Pasteur ukuł pojęcie „zmiennej zachorowalności”, częściowo potwierdzając $\mathrm{w}$ ten sposób środowiskowe uwarunkowanie chorób i czyniąc $z$ higienistów swoich sojuszników ${ }^{14}$. Trzecim krokiem było takie przekształcenie warunków na farmie (np. oddzielenie zwierząt szczepionych od nieszczepionych, pomiary temperatury zwierząt, grupy kontrolne), że proces przeprowadzony w kroku drugim dało się przenieść do środowiska, z którego zjawisko wyizolowano ${ }^{15}$.

Zabiegi zastosowane $\mathrm{w}$ walce $\mathrm{z}$ wąglikiem zostały wykorzystane $\mathrm{w}$ innych sytuacjach, w których niewidzialne bakterie wkraczały jako dodatkowy aktor destabilizujący relacje. Latour, używając terminu „wymuszony punkt przeprawy”, pokazuje, jak Pasteur mógł sprawić, że jego tezy uzyskały status tez bezdyskusyjnych. Higieniści byli jak wojsko broniące długiej granicy. Dążąc do zmiany całego środowiska, pozostawali bezsilni, kiedy chodziło o powstrzymanie małych niewidzialnych przeciwników. Pasteur dokonał transformacji praktyk higienistów, a także rolników i lekarzy, tak że mogli skutecznie stawić czoło bakteriom. Nowa organizacja praktyk polegała na wprowadzeniu dodatkowych procedur w tych miejscach, które bakterie wykorzystywały, aby wkroczyć w określoną sieć relacji i zdestabilizować ją. Te miejsca to właśnie wymuszone punkty przeprawy ${ }^{16}$. Zdefiniowanie wymuszonych punktów przeprawy sprawiło na przykład, że zaprzestano wietrzenia sal operacyjnych i szpitali w celu usunięcia miazmatów, a zaczęto koncentrować się na ranach pacjentów i rękach lekarzy, które utrzymywano w czystości i dezynfekowano ${ }^{17}$. Dzięki laboratorium można było określić, na co odporna jest dana bakteria i w odpowiednim miejscu zastosować wobec niej test siły, którego z bardzo dużym prawdopodobieństwem nie będzie mogła przetrwać. W ten sposób gwarantuje się bezdyskusyjność swoim tezom. Można spierać się, czy prowadzące do ślepoty ostre zapalenia spojówek u noworodków są powodowane przez wyziewy, styl życia matki czy bakterie rzeżączki, ale fakt, że przemycie noworodkom oczu (wymuszony punkt przeprawy) roztworem azotanu srebra (test siły) sprawia, iż liczba zapaleń spojówek spada niemal do zera, jest bezdyskusyjny. W ten sposób uprawia się naukową dyskusję za pomocą innych środków.

Latour zwraca też uwagę, że fakt uznania Pasteura za geniusza i przypisania mu kluczowej roli jako odkrywcy bakterii, nie był ze strony współczesnych zwykłą irracjonalnością, ale spełniał istotną rolę $\mathrm{w}$ zapewnieniu powodzenia całemu procesowi ustanawiania i stabilizowania sieci: „Zrzeszenie sił, które staram się zrekonstruować, mogłoby zostać pomylone z ostatecznym obrazem wytwarzanym przez to zrzeszenie, gdyby nie jedna istotna różnica. Mikroby mogłyby zostać odkryte bez przypisywania szczególnej odpowiedzialności za

\footnotetext{
14 Tamże, s. 63.

15 Tamże, s. 89.

16 Tamże, s. 44

17 Tamże, s. 45-49.
} 
to Pasteurowi. W końcu niewdzięczność w polityce zdarza się częściej niż wdzięczność. Dlatego rozróżnić trzeba dwa mechanizmy. Pierwszy porządkuje siły jedna nad drugą i pozwala nam wyjaśnić, jak epoka zostaje zainteresowana (staje się zainteresowana) tym, co dzieje się w laboratorium Pasteura; drugi mechanizm przypisuje odpowiedzialność za przywództwo jednej osobie spośród wielu. Kiedy Tołstoj wyjaśnia kampanię rosyjską, opisuje pierwszy mechanizm, ale jest świadom, że drugi mechanizm działa inaczej, skoro działania przypisywane są "geniuszowi Napoleona" lub "geniuszowi Kutuzowa». Tak samo jest w bakteriologii. To, co nazywam pierwotnym mechanizmem, ukazuje, jak bakteriologia dostała się na koniec łańcucha pasożytniczego i zdołała wyrazić całą epokę. Wtórny mechanizm przypisuje całość higienicznej rewolucji epoki geniuszowi Pasteura. Pierwotny mechanizm zdaje sprawę z sojuszy i tworzenia się sił, podczas gdy wtórny wyjaśnia, dlaczego siły mieszają się ze sobą pod nazwą, która je reprezentuje. Pierwszy określa «testy sił», drugi wyjaśnia, jak powstaje "moc»" 18. Latour pokazuje, jak zasłonięcie procesu konstruowania sieci warunkuje jej stabilność i długość. Higieniści i współpracownicy Pasteura sprawniej przekonywali innych do rekonstrukcji praktyk, kiedy występowali $\mathrm{w}$ roli reprezentantów autorytetu nauki i geniusza-odkrywcy.

\section{CO Z TEGO WYNIKA?}

Historia Latoura o Pasteurze nie tylko jest ciekawą opowieścią, ma nam także uzmysłowić, że obszar, z jakim mamy do czynienia jako badacze społeczni, nie jest wyłączną domeną aktorów ludzkich. Powinniśmy zrozumieć, że społeczeństwa nie można ustanowić tylko na mocy tego, co społeczne ${ }^{19}$. Budowa gmachu społecznego wyłącznie $z$ relacji społecznych, na przykład lojalności grupowej, wartości czy norm, prowadzi do zakłóceń i rozpadu więzi. Dezynfekcja rąk jest lepszą gwarancją tego, że pacjent przeżyje, niż dobre intencje lekarza albo fakt, że wszystkich pacjentów traktuje on jednakowo.

Latour zwraca uwagę, że nowoczesne stosunki społeczne są formowane nie tylko przez siły wytwórcze albo stosunki władzy, ale także przez robienie miejsca dla nie-ludzkich aktorów. Strach przed chorobami odegrał znaczną rolę $\mathrm{w}$ ustanawianiu bardziej zmedykalizowanych relacji społecznych, ważne jest jednak, aby nie sprowadzać efektów wywołanych uwzględnieniem bakterii do konwencjonalnych wynalazków służących kontroli społecznej. W pismach $z$ epoki zwraca się uwagę na zagrożenie, ale także na zbawienny wpływ „nieskończenie małych". Bakterie łączą nas $\mathrm{w}$ strachu przed śmiertelnymi chorobami, ale także pomagają $\mathrm{w}$ przemyśle spożywczym, są wrogami, ale bywają także partnerami ${ }^{20}$. Latour mówi, że odkrycie tych nowych aktorów powinno

18 Tamże, s. 41-42.

19 Tamże, s. 35.

20 Choćby jako skład jogurtów; tamże, s. 37. 
dać do myślenia socjologii. Nikt nie czeka na socjologa, aby zdefiniował społeczeństwo, aktorzy sami redefiniują to, jak je rozumieją, włączając w jego ramy także nie-ludzkich aktorów. Ich definiowanie jest sprawą innego typu naukowców niż socjologowie - matematyków, fizyków czy biologów. Według Latoura, mają oni ciekawszy ogląd społeczeństwa niż socjologowie, którzy dokonują jego redukcji do mechanizmów panowania lub działania sił wytwórczych.

Socjologowie powinni zatem zrewidować to, co uznają za obszar swoich dociekań. Latour proponuje, aby tym nowym obszarem zainteresowania stały się sieci lub zrzeszenia. Zmiana oznaczałaby konieczność przemyślenia na nowo rodzaju branych pod uwagę aktorów i problemu porządku społecznego, czyli typu więzi, jaki łączy tych aktorów.

Dla rozważenia problemu aktorów kluczowe jest ukazanie, jakich perspektyw Latour unika w opowieści o Pasteurze. Po pierwsze, działania Pasteura nie są traktowane po prostu jako odkrycia. Powiedzenie, że bakterie zostały odkryte, oznaczałoby pominięcie wszystkich praktyk, takich jak przekształcenia procedur spożywczych, hodowlanych i medycznych, które przesądziły o bezdyskusyjności tez Pasteura. Gdyby nie istniały narzędzia statystyczne pokazujące natężenie epidemii, gdyby nie było laboratorium o stabilnych warunkach, sposobów osłabiania bakterii, środków umożliwiających bezpieczny transport szczepionek, gdyby higienistów nie udało się przekonać do istnienia mikrobów i wykonywania odpowiednich testów siły, to odkrycia Pasteura nie wprowadziłyby żadnej różnicy. Żeby odkrycie działało, musi istnieć odpowiednia infrastruktura podtrzymująca jego realność.

Po drugie, Latour unika demaskacji, która denuncjowałaby praktyki w laboratorium i poza nim jako narzucanie arbitralnych działań i treści, które zakrywają asymetryczne stosunki władzy. Branie mikrobów pod uwagę nie jest uprawomocnione jedynie naukowym czy symbolicznym kapitałem Pasteura, ale jest związane $z$ realną różnicą $\mathrm{w}$ stabilności relacji, wiążącą się $\mathrm{z}$ uwzględnieniem niewidzialnych aktorów. Rezygnacja $z$ tych dwóch perspektyw nie oznacza, że Latour uchyla się od odpowiedzi na pytanie o obiektywne istnienie aktorów. $Z$ punktu widzenia ANT pytanie o obiektywne istnienie aktorów nie jest po prostu pytaniem dobrze postawionym. Na aktora trzeba patrzeć nie przez pryzmat prawdziwości, ale jego wytrzymałości, a także relacji, w jakie wchodzi. Bakterie zostają wzięte pod uwagę, ponieważ destabilizują więzi społeczne - gdyby nie istotny problem ze stabilnością relacji obejmujących ludzi i zwierzęta Pasteur zapewne nigdy nie podjąłby się badań nad chorobami i nie wskazałby na bakterie jako ich przyczynę. Bakterie jako nowego aktora można pokazać hodując je w laboratorium, co więcej, można je osłabić, tak że nie będą już silniejsze od człowieka albo zwierzęcia. Aktora należy definiować przez wytrzymałość — każdy ma jakąś granicę, której nie może pokonać. Granice ustanawiane są przez rozmaite testy siły, określające dla danego aktora możliwość lub niemożliwość wchodzenia $\mathrm{w}$ relacje $\mathrm{z}$ innymi aktorami. 
Sposób ujmowania aktorów musi prowadzić do zredefiniowania sposobu rozumienia porządku społecznego. Jeśli socjologia będzie chciała problem porządku rozpatrywać przez pryzmat ładu aksjologiczno-normatywnego, porządku dyskursu albo stosunków panowania, to nie będzie w stanie zdać sprawy z rzeczywistości nowoczesnych społeczeństw. Przypadek Pasteura ukazuje nam $z$ całą mocą, że społeczeństwo nie jest złożone po prostu z relacji społecznych (wartości, normy) albo z siły, albo z reprezentacji. To, co istnieje, to sieci rozmaitej stabilności i długości, które składają się z ludzi i nie-ludzi, a także z języka (dyskursów), technologii, przemocy itd. Lista nie jest zamknięta, ponieważ konstrukcja sieci jest otwarta na nowe metody stabilizacji i rozciągania. O sieciach nie można przesądzać, czy są ludzkie czy nieludzkie, czy tworzą je mikroby czy wartość dodatkowa, można o nich jedynie powiedzieć, czy są mocne czy słabe.

Perspektywa proponowana przez ANT nie polega na odrzuceniu takich pojęć, jak interes, władza czy dyskurs. Zamiast odrzucenia trzeba je tak zmodyfikować, aby nadawały się do wykonywania nieredukcjonistycznych analiz sieci. Weźmy na przykład pojęcie ideologii. Zdefiniowane jako zespół środków symbolicznych umożliwiających odtwarzanie stosunków dominacji, dla Latoura będzie narzędziem redukowania praktyk do epifenomenów stosunków władzy. Jeśli przyjąć, że pojęcie ideologii odnosi się do nieprzejrzystości relacji, jaka łączy aktorów z rzeczywistością i innymi aktorami (fałszywe rozpoznanie), to można spróbować odnieść je do sieci. Odkrycie Pasteura wymagało uczynienia jego tez bezdyskusyjnymi. Stało się to możliwe między innymi dzięki przekonaniu higienistów do istnienia mikrobów, a pomostem dla tego sojuszu było pojęcie „zmiennej zachorowalności”. Dzięki niemu higieniści przyłączyli się do Pasteura, choć jego tezy na temat przyczyn chorób stały w jawnej sprzeczności z wyobrażeniami higienistów o „spontanicznej zachorowalności”. Trawestując myśl Lacana o komunikacji, ideologię można zdefiniować jako z sukcesem przeprowadzone nieporozumienie.

Podobnie jest $z$ tradycyjnie zdefiniowanymi celami stawianymi przed naukami społecznymi. $Z$ jednej strony krytyka jest przez Latoura utożsamiana $\mathrm{z}$ przemocą $\mathrm{w}$ myśleniu (aparat krytyczny) lub socjologicznym redukcjonizmem (redukcja więzi społecznych do stosunków dominacji). $Z$ drugiej strony cele krytyki społecznej, jakimi są ujawnianie asymetrii i reforma stosunków społecznych, są stale obecne w tekstach Latoura.

Po pierwsze, stara się on pokazać, że podążanie najkrótszą drogą wcale nie musi prowadzić do przewidywanych rezultatów. Dążenie do reformy społecznej, choć było bardzo szlachetne, nie przynosiło oczekiwanych skutków. Sukces Pasteura i jego współpracowników wynikał między innymi z tego, że łączyli refleksję nad kilkoma obszarami. Likwidacja problemu epidemii stała się możliwa bez bezpośredniego kontaktu z zakażonymi (praca w laboratorium), a sukces został osiągnięty z pominięciem aktorów społecznych (odkrycie mikrobów). Zwolennicy Pasteura mówili tylko o tych aktorach, których mogli poddać re- 
translacji. Odnowili medycynę, nie rozpatrując nawet kwestii choroby, zmienili politykę i higienę, nie zajmując się biednymi ${ }^{21}$.

Po drugie, Latour pokazuje logikę odpowiedzialną za nieskuteczność krytyki jako demaskacji stosunków władzy. Obnażanie kolejnych konstrukcji jako środków służących tylko temu, aby panować nad ludźmi, nie jest skutecznym narzędziem zmiany społecznej, ponieważ pozbawia konstrukcje podtrzymujące asymetrię między aktorami jakiejkolwiek substancjalnej treści mogącej stanowić wyłom w kompletnym mechanizmie panowania. W ten sposób bardzo radykalnej krytyce towarzyszy ucieczka od konkretnych układów i realnie istniejących relacji: „Zgoda, niech się skarżą, niech się oburzają, krytykują i walczą. To jest potrzebne. Dlaczego jednak, skoro chcą wygrać, podają przeciwnikowi jedyną rzecz, jakiej on potrzebuje, aby sprawować dominację? [...] Powinniśmy nauczyć się podejrzliwości wobec wszystkich, którzy wierzą w "prawdziwe» relacje rynkowe, "prawdziwe» ekwiwalencje, "prawdziwie» naukową dedukcję. Niezależnie od tego, jak byliby oni grzeczni i kulturalni, nie ocalą skarbu, który deklarują chronić. W rzeczywistości ro z brajają tych, którzy mogliby mieć odwagę zmierzyć się z relacjami siły tworzącymi ekwiwalencje, maszyny lub wiedzę. Osłabiają tych, którzy mogliby być może znaleźć siłę, aby zmienić tę wiedzę lub te maszyny" 22 .

Latour przekonuje zatem, że cele krytyki da się osiągnąć niekrytycznymi środkami, choćby dlatego, że to, co uchodzi za najbardziej radykalną krytykę, nie ma mocy zmiany relacji władzy w realnie istniejących sieciach ${ }^{23}$.

\section{PARADOKS W SIECI}

Chęć oddania sprawiedliwości temu, co inne, przez konsekwentne przestrzeganie zasady irredukcjonizmu prowadzi Latoura do specyficznych paradoksów. Warto przywołać choćby pierwsze zacytowane zdanie: „Nic nie jest samo w sobie ani redukowalne, ani nieredukowalne do niczego innego". Latour od razu zaznacza, że to specyficzna reguła, która nie obowiązuje, bo byłaby to sprzeczność. Zauważenie tego paradoksu nie wpędza go jednak w panikę. Istnienie paradoksów nie oznacza przecież niemożności konstruowania sieci. Konstruują się one dzięki zasłonięciu paradoksu ujawniającego się przy obser-

21 Tamże, s. 104. Odkrycia Pasteura doprowadziły też do zmodyfikowania opieki nad chorymi. Lekarze zostali uczynieni funkcjonariuszami publicznymi odpowiedzialnymi za rozpoznanie chorób, a medyczne praktyki zakonnic, szarlatanów i osób nawołujących do samoleczenia zostały znacznie ukrócone.

22 Tamże, s. 208-209.

23 Ostatnio Latour coraz więcej miejsca poświęca na rozważania dotyczące warunków uprawiania demokratycznej polityki i rozwiązywania globalnych problemów związanych z wyzwaniem ekologicznym. W tych pracach zamiast krytyki uprawianej w duchu demaskacji lub denuncjacji pojawiają się projekty zredefiniowania ram ładu politycznego. Zob. B. Latour, Politiques de la nature, La Découverte, Paris 1999; B. Latour, War of the Worlds: What About Peace?, Prickly Paradigm Press, Chicago 2002; B. Latour, Une monde pluriel mais commune, Éditions de l'Aube, La Tour d'Aigues 2005. 
wacji. Ta prawidłowość widoczna była w procesie nadawania statusu geniusza Pasteurowi. Choć na sukces pracowało wielu aktorów, choć był on możliwy dzięki daleko idącym przekształceniom rzeczywistości i zawarciu wielu sojuszy wymagających rekonstrukcji dotychczasowego sposobu istnienia aktorów (np. higienistów, lekarzy, rolników), całość sprowadzono do odkrycia przez geniusza, jak rzeczy mają się naprawdę. Kontyngencję towarzyszącą stabilizowaniu i rozciąganiu sieci można ukazać, jeśli uniknie się redukcji, która dla stabilizacji i rozciągłości ma kluczowe znaczenie.

Inny przykład tego samego procesu Latour i Woolgar przedstawili w Laboratory Life, ukazując, jak konstruowane są fakty naukowe. Nadawanie statusu faktu polega na czynieniu pewnych rzeczy bezdyskusyjnymi. Naukowcy różnymi środkami mogą sprawić, że koledzy zaakceptują określone wyniki jako prawdziwe. Tymi środkami w nowoczesnej nauce laboratoryjnej są na przykład: zastosowanie nowego testu, posłużenie się nowym przyrządem albo wykonanie kosztownych badań, na jakie nie stać konkurentów. Akceptacja łączy się z redukcją poziomu niepewności $\mathrm{w}$ stosunku do określonych wyników, które naukowcy milcząco uznają i czynią elementem postępowania badawczego. Spojrzenie na historię nauki uzmysławia jednak, że fakty milcząco uznawane za realne są efektem konstrukcji i mogą zostać podważone, jeśli pojawią się nowe testy lub nowi sojusznicy. Wiedza o niekonieczności pewnych rozwiązań daje wgląd w kontyngentny charakter sieci, ale nie oznacza automatycznie zdolności do podważenia stabilności określonej sieci. Do tego celu należałoby mieć narzędzia pozwalające na uprawomocnienie innych rozwiązań, które mogłyby zostać potraktowane jako bezdyskusyjne.

Latour w wielu tekstach ukazuje, jak sieci konstytuowane są dzięki czynieniu czegoś nieokreślonego stabilnym i czegoś niejasnego przejrzystym. Zbudowanie sieci jest możliwe tylko dlatego, że rozmaici aktorzy, twierdzenia, maszyny nie mają dookreślonych właściwości, ale ujawniają je, kiedy wchodzą $w$ relacje $z$ innymi aktorami, twierdzeniami i maszynami. Dlatego Latour, aby wskazać naturę elementów, z jakich składa się sieć, używa pojęcia quasi-obiektu (także quasi-podmiotu). Quasi-obiekt to element widziany z perspektywy nieredukcjonistycznej. Zawsze zawiera więcej możliwych właściwości niż te, które definiują go w konkretnych relacjach. I choć stabilizacja sieci wymaga zasłonięcia faktu, że element może być czymś innym, to analiza sieci musi to uwzględnić. Aktorzy są redukowalni do relacji, w jakie wchodzą, bo inaczej nie mogliby wchodzić we względnie stabilne relacje, i zawsze są nieredukowalni, ponieważ pozostaje reszta, która nie pozwala na sprowadzenie aktora do konkretnej tożsamości.

Paradoksy, które towarzyszą tworzeniu sieci, są obecne także podczas tworzenia teorii sieci. Aby to zauważyć, trzeba przywołać sposób rekonstrukcji tradycji socjologicznej pojawiający się w książkach Latoura. Pierre Bourdieu na przykład zostaje potraktowany jako doskonały przykład socjologicznego redukcjonizmu, który polega na sprowadzaniu praktyk społecznych do odwzoro- 
wywania różnic wynikających z władzy ekonomicznej, politycznej i kulturowej. Społeczeństwo składa się $z$ aktorów posiadających zróżnicowany kapitał i rzeczy, które odbijają stosunki między ludźmi. Nic nie może zostać zredukowane do niczego innego, chyba że jest to teoria Bourdieu. Nie trzeba być wielkim znawcą tej teorii, żeby zauważyć, jak dalece redukcjonistyczna jest rekonstrukcja Latoura. Znika cały wysiłek autora Dystynkcji, polegający na zarysowaniu przestrzeni walk otwieranych przez zapośredniczenie relacji społecznych przez rzeczy, a zwłaszcza przez idee, takie jak równość czy wolność ${ }^{24}$. Nie o to jednak chodzi, by wytykać Latourowi błędne odczytanie teorii Bourdieu, ale o wskazanie, że praca redukcji i zasłaniania procesu stabilizacji elementu sieci występuje w samej teorii Latoura. Proces budowania teorii przebiega zgodnie $z$ ogólnymi zasadami budowania sieci i redukowanie jest tego procesu nieodłączną częścią.

O doniosłości teoretyka stanowi to, że przekształca on pole rozważań w taki sposób, iż stare problemy ukazują się $\mathrm{w}$ nowym świetle, zmuszając do przemyślenia dotychczasowych sposobów stawiania pytań i udzielania odpowiedzi. Takim teoretykiem na pewno stara się być Bruno Latour. Poruszając problem władzy, technologii, nowoczesności czy porządku społecznego, podejmuje tematy kluczowe dla teorii społecznej, a pojęcia takie jak sieć, aktor, test siły czy wymuszony punkt przeprawy nie są nowymi butelkami na stare wino, ale wyznaczają nowy obszar rozważań dla teorii społecznej. W tym obszarze szczególne znaczenie uzyskują pytania o granice konstruktywizmu, rolę krytyki i wielość aktorów społecznych (ludzkie i nie-ludzkie). Teksty Latoura należą do najbardziej inspirujących współczesnych osiągnięć teorii społecznej i są świadectwem, że pogłoski o śmierci wielkiej teorii były z pewnością przesadzone.

\section{SOCIOLOGY OF THE END OF SOCIOLOGY ON BRUNO LATOUR'S THEORETICAL CONCEPT}

Summary

The article presents the main theoretical ideas developed by Bruno Latour. The method of presentation consists in following the stories told by Latour which allow the author to better grasp the theory which otherwise resists demonstration. Latour redefines the very subject of sociology and transforms the notions used in the description and explanation of social processes. The article presents the paradoxes involved in this theoretical project.

Key words/słowa kluczowe sociological theory / teoria socjologiczna; networks / sieci

24 Zob. P. Bourdieu, Dystynkcja, tłum. P. Biłos, Scholar, Warszawa 2005; P. Bourdieu, Medytacje pascaliańskie, tłum. K. Wakar, Oficyna Naukowa, Warszawa 2006. 